\title{
An Evaluation of Textbooks Designed for Advanced English Learners Within a Foreign Context: A Critical Thinking Perspective
}

\author{
EBRahim Khodadady and MaliheH Karami \\ Ferdowsi University of Mashhad, Iran
}

Received: 18 May 2016 / Accepted: 10 April 2017

ISSN: $1697-7467$

\begin{abstract}
The present study explored the relationships between inference and deduction abilities as two aspects of critical thinking (CT), tasks dealing with the CT and its two aspects, and the English language achievement (ELA) of advanced learners of English as a foreign language in Iran. To this end, the 172 participants' scores obtained in the last three semesters were averaged and correlated with the shortened Persian Watson-Glaser Critical Thinking Appraisal and its two inference and deduction subtests. Significant relationships were found between the ELA and CT. Tasks based on the CT also correlated significantly with the ELA, leading to suggestions made for future research.
\end{abstract}

Keywords: critical thinking, inference, deduction, evaluation

Una evaluación de los libros de texto diseñados para estudiantes avanzados de inglés dentro de un contexto extranjero: una perspectiva de pensamiento crítico

RESUMEN: El presente estudio exploró las relaciones entre las habilidades de inferencia y deducción como dos aspectos del pensamiento crítico (CT), tareas relacionadas con la CT y sus dos aspectos, y el logro en el idioma inglés (ELA) de los estudiantes avanzados de inglés como lengua extranjera en Irán. Con este fin, los 172 resultados de los participantes obtenidos en los últimos tres semestres se promediaron y se correlacionaron con la evaluación abreviada del pensamiento crítico persa Watson-Glaser y sus dos subpruebas de inferencia y deducción. Se encontraron relaciones significativas entre ELA y CT. Las tareas basadas en la CT también se correlacionaron significativamente con la ELA, lo que condujo a sugerencias hechas para futuras investigaciones.

Palabras clave: pensamiento crítico, inferencia, deducción, evaluación

\section{INTRODUCTION}

It is generally agreed among experts that education plays a pivotal role in the growth and development of any country. According to many educationalists such as Dewey (1910) and de Bono (1976), the aim of education is to teach learners to think. However, the educational systems in some countries, including Iran, focus mainly on teaching "what to think" rather than "how to think" effectively (Schafersman, 1991), considered as critical thinking CT. It is further elaborated as "the ability to analyze, criticize, and advocate ideas; to reason inductively and deductively; and to reach factual or judgmental conclusions based on sound inferences 
drawn from unambiguous statements of knowledge or belief" (Freeley \& Steinberg, 2000: 2). Due to its indispensible role in learning, CT has recently become one of the noticeable issues in the realm of education, especially in the area of foreign language teaching. The skills involved in CT are also considered essential because they enable students "to deal effectively with social, scientific, and practical problems" (Shakirova, 2007:42), especially when they are brought up in textbooks designed to teach English as a foreign language (EFL).

Many scholars in the field (e. g., Hutchinson \& Torres, 1994) have emphasized the pivotal role of EFL textbooks in classroom dynamics. As a result, there is a need for teachers and researchers to evaluate the textbooks that are used in the EFL classrooms in order to find out whether they incorporate issues such as CT skills playing significant role in learners' school and academic achievement. The present study, therefore, seeks to first, shed more light on the relationship between critical thinking ability of Iranian learners and their EFL achievement and second, evaluate the Iran Language Institute (ILI) Advanced Series textbooks with respect to their fostering critical thinking skills based on Watson-Glaser's model.

\section{Theoretical BaCKGround}

\subsection{Critical thinking}

It was the Greek philosopher Socrates who first set the agenda for critical thinking (Fahim \& Bagheri, 2012). However, in modern times the theory of critical thinking began with the works of Bloom (1956). Recent research within the domain of EFL teaching has also shed light on the increasing importance of those CT skills that enable students to solve various perplexities they encounter in the process of language learning (Waters, 2006).

A review of the literature reveals that various definitions of critical thinking have been offered by different researchers in the field. Norris (1985), for example, defined critical thinking as the ability that helps students apply what they already know to evaluate their own thinking. Schafersman (1991:3), however, described it as "reasonable, reflective, responsible, and skillful thinking that is focused on deciding what to believe or do."

According to Pithers and Soden (2000), critical thinking is a cognitive ability including multiple skills such as identifying, understanding, and analyzing an issue by applying inferences using top-down and bottom-up strategies to assess the reliability of claims or arguments. Paul and Elder (2006) referred to critical thinking as the art of analyzing and evaluating thinking with a view to improving it.

In the same vein, Liaw (2007: 51) regarded critical thinking as something which "involves the use of information, experience, and world knowledge in ways which allow [EFL students] to seek alternatives, make inferences, pose questions, and solve problems, thereby signaling understanding in a variety of complex ways." By considering CT the metaphorical bridge between information and action, Rubenfeld and scheffer (2010) argued that "this bridge is invisible from one perception into something visible from a new perspective" ( $\mathrm{p}$. 26). Similarly, Watson and Glaser (2012) described it as the ability to identify and analyse problems as well as seek and evaluate relevant information in order to reach an appropriate conclusion. 
As the definitions mentioned above indicate, there is a lack of consensus on what CT exactly stands for. To escape the limitations of a single definition as outlined by Khodadady (2013), some frameworks which consist of different perspectives including alternative definitions can be created. As cited in Talebinezhad and Matou (2012), critical thinking process includes eight components: perception, assumption, emotion, language, argument, fallacy, logic, and problem solving. Similarly, in 1956 Bloom and his colleagues outlined six levels of critical thinking: knowledge, comprehension, application, analysis, synthesis, and evaluation. The Delphi Report (1990) has also provided a list of core cognitive skills and sub-skills of CT including interpretation, analysis, evaluation, inference, explanation, and self -regulation. They seem to be captured by Watson and Glaser (Glaser, 1937; Watson \& Glaser, 1994, cited in user guide 2012) who believed critical thinking includes

- attitudes of inquiry that involve an ability to recognize the existence of problems and an acceptance of the general need for evidence in support of what is asserted to be true,

- knowledge of the nature of valid inferences, abstractions, and generalizations in which the weight or accuracy of different kinds of evidence are logically determined, and

- $\quad$ skills in employing and applying the above attitudes and knowledge.

As mentioned before, the significance of $\mathrm{CT}$ in education is acknowledged by a

large number of educators. Lipman (1984), for example, asserted the emphasis in education is shifting from the acquisition of facts to the process of thinking so that the students can think for themselves. Furthermore, CT has a pivotal role in EFL teaching and learning. Researchers believe that in order to promote proficiency in English as a second language (ESL) learners, higher-order thinking skills especially CT should be an integral part of L2 curriculum (Liaw, 2007). The present study, therefore, aims to find out whether it should become an integral part of EFL textbooks.

\subsection{Textbook evaluation}

According to Sheldon (1987), a textbook is a book specially designed to help language learners improve their linguistic and communicative abilities. A textbook is an essential component of EFL classes and most of the ELT professionals incorporate the use of textbooks in their daily teaching practices. As Sheldon (1988: 239) put it, "coursebooks are perceived by many to be the route map of any ELT program." Similarly, Hutchinson and Torres (1994: 315) maintained "The textbook is an almost universal element of ELT teaching which shapes the teaching and learning process by providing the required structure." Besides, the textbook is one of the crucial factors in determining the learners' ultimate achievement.

Using textbooks in the language teaching and learning process involves some advantages as well as disadvantages. The structure of the textbook can provide the teacher with a blueprint as to how to conduct the lessons (Hutchinson \& Torres, 1994). 
Textbooks can also serve as a focus for teaching so that the progress made in teaching and learning can be measured (Tomlinson, 2008). Moreover, based on McGrath (2002), textbooks can function as a map showing the teaching progress as well as facilitating curriculum change. Textbooks are also especially useful gadgets for novice teachers because they provide security so that their confidence is increased (Mares, 2003). In addition to helping teachers, textbooks can also be useful devices for learners, for instance, as a reference for keeping track of their development (O'Neil, 1982).

Despite the great significance of textbooks, there is no unanimous agreement among researchers as to whether the use of textbooks in EFL teaching can help or hinder the teaching and learning process. Textbooks, for example, are said to have some disadvantages: some teachers may become dependent on the textbook and thus, uncreative in teaching (Tomlinson, 2008). Also, according to McGrath (2002), they may take the book for granted and become uncritical of the content of the book. Also, in a strong exam-oriented culture, such as Iran, textbooks are often regarded as exam practice sessions rather than a tool for facilitating successful language acquisition (Tomlinson, 2008). The structure of the textbook may, furthermore, inhibit creativity and imagination during the learning and teaching process (Ur, 1996).

Regarding the aforementioned points as well as the fact that an ever increasing number of textbooks are available on the market, it becomes clear that teachers have a tough job in making decisions about the most appropriate textbook for their students which meets their needs. According to Mukundan (2007), for example, the quality of the textbook is one of the determining factors in the success or failure of an EFL program. However, textbooks are usually chosen not based on careful analysis but based on factors such as being the bestsellers used in other places (Tomlinson, 2010). Furthermore, many publishers print books that are developed for commercial purposes rather than those that are based on the principles of foreign language learning as identified by experts in the field.

Taking all these points into account, it is vital for teachers or curriculum developers to conduct EFL textbook evaluation so that they can select the teaching materials that facilitate achieving the objectives of the courses offered in educational centers such as the ILI. The importance of evaluation will increase if research projects such as the present study show that CT relates significantly to the EFL learners' achievement enrolled in these centers.

\subsection{Related studies}

\subsubsection{Critical thinking and language proficiency}

In 2014, Jafari, Assadi, and Zoghi conducted a study on the effect of CT strategies instruction on Iranian EFL learners' writing performance and found that they had a significant effect on improving the students' writings across genders.

Grosser and Nel (2013) explored the relationships between the CT skills and the 
academic language proficiency of a group of first-year prospective teachers at a South African university. The results indicated significant correlations between the proficiency and CT as a general competency as well as some of its subcomponents such as making inferences.

Keihaniyan (2013) investigated the CT ability of 100 undergraduate university students and explored its relationship with their English language proficiency. The results established a significant and positive relationship between the ability and proficiency.

\subsubsection{Critical thinking and textbook evaluation}

Some studies have evaluated EFL textbooks from the perspective of cognitive skills. Riazi and Mosalanejad (2010), for example, carried out a study about the types of learning objectives in Iranian senior high school and pre-university textbooks based on Bloom's revised taxonomy (BRT) learning objectives. The findings disclosed the dominance of lower-order cognitive skills in all the grades.

Birjandi and Alizadeh (2012) investigated the extent to which CT skills in three English textbooks, namely Top Notch, Interchange, and English File series were involved. The results revealed that these three textbooks mostly included skills such as knowledge, comprehension, application, and building community of thinkers and lacked other types of skills.

In their study, Razmjoo and Kazempourfard (2012) used BRT to evaluate learning objectives in the Interchange series. As a result, the prevalence of lower-order thinking skills including remembering, understanding, and applying as well as lack of metacognitive knowledge was reported.

Talebinezhad and Matou (2012) examined how frequently and to what extent critical thinking is advocated in EFL Reading Comprehension textbooks at university level in Iran. The findings indicated that high attention was paid to critical thinking within the objectives of the questions of their course books and the authors of the passages.

In another study Roohani, Taheri, and Poorzangeneh (2014) evaluated two ELT textbooks based on BRT. The results revealed the prevalence of the processes of remembering and understanding in the textbooks. Also, creating process constituted the lowest percentage of processes in both textbooks. Furthermore, the lower-order categories were more frequently represented than the higher-order ones (i.e., analysing, evaluating, and creating). They concluded that these textbooks fail to engage learners well in the activities requiring higher levels of cognitive ability which are the prerequisites of autonomous language learning.

While the studies mentioned above have focused solely on the type of tasks presented in the EFL textbooks, the present study has explored whether there is any significant relationship between inference and deduction as two components of CT on the one hand, and the English language achievement of EFL learners on the other. The three advanced textbooks taught at the ILI were also analysed in terms of their tasks dealing with CT and its components and related them to EFL achievement. 


\section{Methodology}

In this section information about the data collection and data analysis procedures, including the materials and instruments utilized, the participants taking part in the study, as well as the steps taken to analyze the data are presented.

\subsection{Materials}

The ILI is a popular and well-known institute in Iran which is preferred by many teachers, parents and learners to other institutes. All the adult courses of the ILI are based on The ILI English Series, materials developed by the Research and Planning Department to be specifically used at ILI classes. The adult section of ILI consists of Basic, Elementary, Pre-Intermediate, Intermediate, High-Intermediate and Advanced levels, each of which contains three sub-levels and three textbooks. The three advanced textbooks analysed here, Advanced 1, 2 and 3, are taught in the last three levels of the ILI. These textbooks are almost of the same size running for 134 pages. Each of them consists of six units and two progress tests; one in the middle and one at the end of each textbook. Every unit has four sections, each covering listening, reading, speaking and writing activities.

\subsection{Instrumentation}

To obtain the data on the EFL learners' CT ability, participants were required to complete the Persian Watson-Glaser Critical Thinking Appraisal (Form A) [WGCTA] voluntarily. The measure consists of five distinct subtests with 16 items in each: Inference, Recognizing unstated assumptions, Deduction, Interpretation, and Evaluation of arguments. In the present study, the first and the third sections of the questionnaire, i.e. tests measuring inference and deduction abilities, were utilized. Only these two subtests were chosen because few test takers volunteered to sit for the 80-item WGCTA.

The first inference subtest measures the ability to discriminate among degrees of truth or falsity of conclusion (inference) drawn from given information. In this section each exercise begins with a statement of facts that are considered true. After each statement of facts several possible inferences are, however, provided which require the participants to make a decision as to its degree of truth or falsity; in other words, they should decide whether the conclusion is definitely true, probably true, probably false, false, or that the given data is insufficient to make such a decision.

The second deduction subtest assesses the test takers' ability to decide whether certain conclusions necessarily follow from information in given statements or premises. Each exercise in this test consists of several premises, which should be regarded as true, followed by some suggested conclusions. The participants are required to decide whether the conclusion necessarily follows from the statements given or not. 


\subsection{Participants}

A total number of 180 advanced EFL learners who had registered at the ILI branches in three Iranian provinces namely, Mashhad, Kerman, and Yazd, participated in this study voluntarily. Available sampling technique was employed in the current study as in this procedure all the available members of the population had an equal and independent chance of being included in the sample (Ary, Jacob, \& Razavieh, 1972). Since eight of the questionnaires were left out due to incomplete answers, the sample consisted of 172, eight male and 164 female, EFL learners. Their age ranged between 16 and 28 $($ Mean $=18.70, \mathrm{SD}=2.24)$. They spoke Persian as their mother language.

\subsection{Procedures}

The shortened Persian Watson-Glaser Critical Thinking Appraisal (Form A) was distributed among the participants during the winter and spring semesters (from January to June 2015). Besides, as the measure of their language achievement, the learners' scores obtained in their last three semesters were taken from the registrar's office of the institute; then, the average of these three scores was adopted as an index of the EFL achievement as most researchers do (e.g., Aida, 1994). Furthermore, setting Watson-Glaser's model of critical thinking as the framework, this study investigated the manifestation of inference and deduction skills at the ILI Advanced Series. To do so, content analysis was conducted on all the activities in the three textbooks in the ILI advanced series, i.e. Advanced 1, Advanced 2, and Advanced 3, to determine the number and frequency of tasks dealing with these skills in each book so that their relationships with the English language achievement could be examined.

Figure 1 , for example, displays an activity developed on a reading passage in advanced 1 textbook. In this activity EFL students are required to use the information they get from the passage and choose the best answer from among the four options. In so doing, they must draw a conclusion about the main topic of the text based on the facts given in the passage; thus, it is subsumed under the domain of inference skill in this study.

B READING FOR DETAILS

Think about what you learned in the passage, and circle the best answer.

1. What is the main topic of the article?
a. The most important goal of education is to improve reading and writing abilities
b. Boys and girls must be taught different subjects at school.
v. Gender differences can account for the different ways boys and girls learn.
d. There should be equal job opportunities for both boys and girls.

Figure 1: A Sample Shot of Inference Activity 
Figure 2 shows an activity in a listening section taken from Advanced 2. This activity is the second task in the listening section. In the first task, the EFL students listen to a conversation about art forgeries and answer two wh-questions. In the listening task 2 given in the figure, the learners are required to listen to the conversation for the second time and decide whether the statements, i.e. deductions, made on the basis of the oral conversation are true or false. This activity involves deduction ability because it exposes the learners to a conversation which should be considered as consisting of a set of premises that are true without exception. Then, the EFL learners are to decide if the deductions made are true or not based on the conversation.

\section{LISTENING TASK 2}

Listen to the conversation again. Write $T$ for true or $F$ for false for each statement.
Then compare your answers with a partner.

T 1. Buyers should learn as much as they can about the artist's style.
F 2. Buyers should talk to the painting's prover.

$F$ 2. Buyers should talk to the painting's previous owners.
$F$ 3. The art dealers will be fined twice as mus sell a fake. T 4. Holding a black light to a painting may reveal if it is a copy.
T 5. The chemical composition of the paint may help determine if a
not.

T 6. Comparing fingerprints left in paint helps in detecting a forgery.

F 7. It is always possible to identify a forged painting.

F 8. Vermeer, Picasso, and Dali are the only artists whos

F 9. Most public and private collections have no forgeries at all.

T 10. Some forgeries have become valuable themselves.

Figure 2: A Sample Shot of Deduction Activity

\subsection{Data analysis}

Following Thorndike (2005) and Baker (1989), item discrimination indices of questions comprising the Persian critical thinking test (CTT) were estimated by correlating each individual item with the total score obtained on the test. The same procedure was followed for its inference (IS) and deduction subtests (DS). The item facility indices were also estimated by dividing the number of correct responses given to each item by the total number of answers given to the CTT, IS and DS. These two indices are usually employed to determine the internal validity of tests. Furthermore, Cronbach's Alpha was estimated to determine the internal consistency of the CTT, IS and DS. And finally, the scores obtained on the measures were correlated with the average English language achievement (ELA) scores to explore the relationship between CT as well as its constituting inference and deduction abilities and ELA. The ELA and CTT scores were also correlated with the number of inference and deduction tasks given in the 
three textbooks to find out whether these tasks contribute to ELA and CT ability. The Statistical Package for Social Science (SPSS) version 20 was utilized to run the statistical analyses and test the following hypotheses:

H01: There is no significant relationship between CT ability and ELA.

H02: There is no significant relationship between inference ability and ELA.

H03: There is no significant relationship between deduction ability and ELA.

H04: There is no significant relationship between CT tasks and ELA.

H05: There is no significant relationship between inference tasks and ELA.

H06: There is no significant relationship between deduction tasks and ELA.

\section{Results}

Table 1 presents the descriptive statistics of the scores obtained on the CTT and its inference and deduction subtests. As can be seen, the mean score on the CCT is 17, indicating that out 32 items, the test takers could answer more than half of the questions correctly. The mean score on the inference subtest (6.9) is, however, noticeably lower than that of deduction subtest (10.03), indicating that the former was very difficult because on average 57 percent of its 16 items could not be answered correctly, i.e., mean $\mathrm{IF}=.43$. The very difficulty of the inference subtest has resulted in its comparatively low alpha reliability coefficient, i.e., 0.51 .

Table 1. Descriptive statistics and reliability estimates of CTT and its two subtests

\begin{tabular}{lccccc}
\hline Tests & \# of items & Mean & Mean IF & Mean ID & Alpha \\
\hline Inference subtest & 16 & 6.9 & 0.43 & 0.32 & 0.51 \\
Deduction subtest & 16 & 10.03 & 0.63 & 0.31 & 0.59 \\
CTT & 32 & 16.94 & 0.53 & 0.24 & 0.53 \\
\hline
\end{tabular}

Table 2 presents the number of Inference and deduction tasks given in each unit of advanced 1, 2 and 3 textbooks taught at the ILI. As can be seen, the number of inference tasks presented in Advanced 1 (94) is more than advanced 2 (84) and Advanced 3 (83). However, the number of deduction tasks in Advanced 1 (70) is less than that of Advanced 2 (84) and Advanced 3 (75). In spite of differences in the total number of tasks, each unit of the Advanced 2 and 3 contains almost the same number of inference and deduction tasks. Advanced 1 is the only textbook in which the number of inference tasks jumps to 30 in unit 5 dropping to 14 in unit 6 . The sum of tasks given in each textbook was taken as a score obtained by each participant when she performed them all at the end of the term and sat for achievement tests. 
Table 2. The number of Inference and deduction tasks given in each unit of textbooks

\begin{tabular}{ccccccccc}
\hline Textbook & Task & Unit 1 & Unit 2 & Unit 3 & Unit 4 & Unit 5 & Unit 6 & Sum \\
\hline \multirow{2}{*}{ Advanced 1 } & Inference & 15 & 14 & 8 & 13 & 30 & 14 & 94 \\
& Deduction & 10 & 10 & 10 & 10 & 15 & 15 & 70 \\
\hline \multirow{2}{*}{ Advanced 2 } & Inference & 16 & 12 & 14 & 12 & 12 & 18 & 84 \\
& Deduction & 11 & 16 & 15 & 15 & 10 & 15 & 82 \\
\hline \multirow{2}{*}{ Advanced 3 } & Inference & 11 & 15 & 14 & 18 & 11 & 14 & 83 \\
& Deduction & 14 & 13 & 16 & 11 & 10 & 11 & 75 \\
\hline
\end{tabular}

Table 3 presents the correlations of English language achievement scores (ELAS) with inference and deduction tasks and subtests forming CT tasks and test. As can be seen, the ELAS correlates significantly with the CTT $(\mathrm{r}=.45, p<.01)$, IS $(\mathrm{r}=.38, p$ $<.01)$ and DS $(\mathrm{r}=.26, p<.01)$ and thus rejects the first, second, and third hypotheses that there is no significant relationship between $C T$ and its constituting inference and deduction abilities and ELA.

Table 3. Correlations of English language achievement scores (ELAS) with and CTT and its tasks and subtests $(N=172)$

\begin{tabular}{lccccccc}
\hline Tasks and Tests & IT & DT & CT Task & IS & DS & CTT & ELAS \\
\hline Inference Tasks (IT) & 1 & $-.827^{* *}$ & $.260^{* *}$ & -0.101 & $.210^{* *}$ & 0.092 & -0.114 \\
Deduction Tasks (DT) & $-.827^{* *}$ & 1 & $.328^{* *}$ & 0.03 & $-.240^{* *}$ & $-.161^{*}$ & -0.021 \\
Critical thinking (CT) Task & $.260^{* *}$ & $.328^{* *}$ & 1 & -0.118 & -0.059 & -0.123 & $-.227^{* *}$ \\
Inference Subtest (IS) & -0.101 & 0.03 & -0.118 & 1 & -0.008 & $.657^{* *}$ & $.379^{* *}$ \\
Deduction Subtest (DS) & $.210^{* *}$ & $-.240^{* *}$ & -0.059 & -0.008 & 1 & $.749^{* *}$ & $.262^{* *}$ \\
Critical Thinking Test (CTT) & 0.092 & $-.161^{*}$ & -0.123 & $.657^{* *}$ & $.749^{* *}$ & 1 & $.449^{* *}$ \\
ELAS & -0.114 & -0.021 & $-.227^{* *}$ & $.379^{* *}$ & $.262^{* *}$ & $.449^{* *}$ & 1 \\
\hline
\end{tabular}

** Correlation is significant at the 0.01 level (2-tailed)

* Correlation is significant at the 0.05 level (2-tailed)

The results presented in Table 3 above also show that the CT Task correlates significantly 
but negatively with the ELAS $(\mathrm{r}=-.23, p<.01)$ and thus rejects the fourth hypothesis that there is no significant relationship between CT tasks and ELA. The IT and DT do not, however, correlate significantly with the ELAS and confirm the fifth and sixth hypotheses that neither inference nor deduction tasks correlate significantly with English language achievement.

\section{Discussions}

The findings of the present investigation revealed that higher levels of CT were associated with higher levels of ELA. This finding is in line with those of previous studies establishing a positive relationship between CT ability and proficiency in language. Grosser and Nel (2013), for example, used the WGCTA and reported a correlation coefficient of $\mathrm{r}=0.414, p<0.01$. Similarly, the results of Rashid and Hashim's (2008) study revealed that the Cornell Critical Thinking Test (CCTT) was significantly and positively correlated to English language proficiency (ELP) measured by the Malaysian University English Language Test (MUET). However, Zarei and Haghgoo's (2012) study on the relationship between CT and L2 grammatical and lexical knowledge indicated that the correlation between vocabulary and CT, on the one hand, and grammar and $\mathrm{CT}$, on the other hand, were not statistically significant.

The difference between the findings of the present study and those of Zarei and Haghgoo (2012) is best explained by the microstructural approach of schema theory (MICAST) which approaches CT, ELA and ELP as cognitive processes. They depend on acquiring and activating concepts represented by words, i.e., schemata, and relating them to each other to produce the broader concepts of species, genera and domain within a hierarchical system. Khodadady and Moosavi (2014), for example, translated the Spiritual Intelligence Self-Report Inventory (SISRI) designed by King (2008) into Persian and administered it to 344 female grade three senior high school (G3SHS) students in Mashhad, Iran. Their linguistic analysis of the inventory and application of principal axis factoring and Varimax with Kaiser Normalization to the data showed that 112 schemata (represented by 112 words) form the 21 species (represented by 21 sentences) and seven genera (represented by seven statistical factors) constituted spiritual intelligence as a cognitive domain measured by the Persian SISRI.

Khodadady and Moosavi (2015) correlated the genera and domain of spiritual intelligence with G3SHS students' scores on their final English language examination. They realized that as a measure of ELA domain the examination does not show any significant relationship with spiritual intelligence. Three out of seven genera constituting the domain of spiritual intelligence did, however, correlate with the examination, i.e., meta-conscious genus $(\mathrm{r}=-.17, p<.01)$, transcending genus $(\mathrm{r}=.13, p<.05)$ and visionary genus $(\mathrm{r}=-.11, p<.05)$. Based on these findings it can be said that as cognitive domains CT, ELA and ELP do relate significantly to each other. However, as the genera of ELP, the grammar and vocabulary subtests of the TOEFL do not correlate with the CT domain, perhaps because of the objective nature of their constituting items. 
Khodadady and Dastgahian's (2015a) findings, for example, revealed that subjective measures such as ELA scores show significant relationships with the domain of teacher effectiveness, i.e., $\mathrm{r}=.154, p<.01$. However, when objective measures such as S-Tests consisting of multiple choice items are employed, ELA does not relate to teacher effectiveness any more, i.e., $r=-.08, n s$ (Khodadady \& Dastgahian, 2015b). The ELA scores employed in this study include the teachers' evaluations of their learners' speaking as well as listening abilities based on their class activities and discussions. While reading can be measured objectively, it is impossible to do so with speaking and writing simply because whatever is said in speaking and written in essays varies from learners to learners. Almost all scholars, therefore, accept that assessing speaking and writing is subjective by its very nature (e.g., Alderson, Clapham, \& Wall, 1995; Hughes, 1989). Similarly, the CT correlated significantly with the ELP because the scores on the MUET were obtained on the "main language skills such as speaking, reading, writing and grammar" (Rashid \& Hashim, 2008: 375).

The most interesting finding of this study is the significant but negative relationship between CT tasks and ELA, showing that the more tasks are given to the EFL learners, the less they achieve in the English language. It challenges scholars such as Schafersman (1991) who believed course books should help students learn how to think rather than simply what to think. If the passages comprising the three textbooks are taken as what to teach and the CT tasks are adopted as exercises to help the EFL learners how to think, then, what to teach helps them think more critically than how to teach. In other words, the differentiation of what from how is questionable and unsubstantiated. Future research is, however, needed to find out whether the other aspects of CT such as recognizing unstated assumptions or interpretation relate to ELA significantly. Replicating the study with an S-Test as a measure of ELA may shed more light on CT and achievement as well.

\section{Conclusions}

Critical thinking as a cognitive domain does relate to English language achievement when it is measured subjectively. The tasks designed to help learners think critically, however, relate negatively to the achievement, indicating that the three textbooks composed for advanced levels by the ILI do not provide satisfactory materials for teaching EFL. The MICAST analysis of the textbooks, however, shows that they serve the purpose well. The difference in the findings lies in the fact that critical thinking tasks do not address concepts such as schemata, species and genera cognitively. Khodadady and Samarvarchi (2015), for example, analysed the reading passages of the three advanced textbooks taught in the ILI and found that 4723 semantic word types (8413 tokens) have been joined together by 601 and 567 syntactic and parasyntactic word types ( 8243 and 1661 tokens), respectively, to create some 1000 sentences and 180 paragraphs. They suggested

teachers can regard schemata represented by words as the basic units of language, the combination and interaction of which with each other will create species 
represented by sentences, thereby making their teaching and instructions realizable. In particular, when dealing with reading comprehension, teachers can try to activate learners' schemata, especially the semantic ones, by employing different techniques and thus enable learners to associate the different schemata with each other in order to enhance comprehensibility.

Tasks designed for critical thinking do not address schemata and their combination with each other within the broader contexts of sentences and paragraphs in that some of them require the EFL learners to read a sentence and provide a positive or negative response whose correctness depends fifty percent on chance! For example, how can listening to a tape for the second time and deciding whether the species "buyers should learn as much as they can about the artist's style" is true or false help the EFL students learn how to think, i.e., deduction, when the answer is already there in the tape! Tasks such as this will neither render thinking critically nor result in achievement as the main purpose of all educational programs.

\section{REFERENCES}

Aida, Y. (1994). "Examination of Horwitz, Horwitz and Cope's construct of foreign language anxiety: The case of students of Japanese", in The Modern Language Journal, 78, 2: 155-168.

Alderson, C., Clapham, C., \& Wall, D. (1995). Language Test Construction and Evaluation. Oxford: Cambridge University Press.

Ary, D., Jacob, L. C., \& Razavieh, A. (1972). Introduction to Research in Education. New York: Holt, Rinehart, and Winston.

Baker, D. (1989). Language Testing: A Critical Survey and Practical Guide. London: Edward Arnold.

Birjandi, P., \& Alizadeh, E. (2012). "Manifestation of critical thinking skills in the English textbooks employed by language institutes in Iran", in International Journal of Research Studies in Language Learning, 2, 1: 27-28.

Bloom, B. (1956). A Taxonomy of Educational Objectives: Handbook 1, Cognitive Domain. New York: McKay.

DeBono, E. (1976). Teaching Thinking. London: Maurice Temple Smith

Dewey, J. (1910). How We Think. Boston, MA: Heath.

Fahim, M., \& Bagheri, M. B. (2012). "Fostering critical thinking through Socrates' questioning in Iranian language institutes", in Journal of Language Teaching and Research, 3, 6: 1122-1127.

Freely, A. J., \& Steinberg, D. L. (2000). Argumentation and Debate: Critical Thinking for Reasoned Decision-Making. Stamford: Wadsworth.

Grosser, M. M., \&Nel, M. (2013). "The relationship between the critical thinking skills and the academic language proficiency of prospective teachers", in South African Journal of Education, 33, 2: 1-17.

Hughes, A. (1989). Testing for Language Teachers. New York: Cambridge University Press.

Hutchinson, T., \& Torres, E. (1994). "The textbook as agent of change", in ELT Journal, 48, 4: 315-328.

Jafari, P., Assadi, N., \& Zoghi, M. (2014). "The effect of critical thinking strategies instruction 
on Iranian EFL learners' writing performance across genders", in International Journal of Advancements in Research \& Technology, 3,4:106-116.

Keihaniyan, M. (2013). "Critical thinking and language proficiency", in The International Journal of Language Learning and Applied Linguistics World, 4, 3: 24-29.

Khodadady, E. (2013). Research Principles, Methods and Statistics in Applied Linguistics. Mashhad: Hamsayeh Aftab

E., \& Dastgahian, B. S. (2015a). "Teacher effectiveness, educational grade and English achievement", in Theory and Practice in Language Studies, 5, 8: 1552-1562.

, E., \& Dastgahian, B. S. (2015b). "Schema-based English achievement and teacher effectiveness", in Theory and Practice in Language Studies, 5,5): 1037-1046.

, E., \& Moosavi, E. G. (2014). "Spiritual intelligence of grade three senior high school students in Iran: A factorial and theoretical approach", in International Journal of Applied Psychology, 4, 4: 134-146.

E., \& Moosavi, E. G. (2015). "Spiritual intelligence and English language learning at a specific grade in secondary education", in Journal of Language Teaching and Research, 5,9: 1801-1808.

, E., \& Samarvarchi, L. (2015). "Schema-based textual analysis of textbooks taught at advanced levels in Iran Language Institute". Manuscript submitted for publication.

King, D. B. (2008). Rethinking claims of spiritual intelligence: A definition, model, and measure. Unpublished Master's Thesis, Trent University, Peterborough, Ontario, Canada.

Liaw, M. (2007). "Content-based reading and writing for critical thinking skills in an EFL context", in English Teaching and Learning, 31, 2: 45-87.

Lipman, M. (1984). "The cultivation of reasoning through philosophy", in Educational leadership, 42, 1: 51-56.

Mares, C. (2003). "Writing a course book", in B. Tomlinson (ed.), Developing Materials for Language Teaching. London: Continuum, 130-140.

McGrath, I. (2002). Materials Evaluation and Design for Language Teaching. Edinburgh: Edinburgh University Press.

Mukundan, J. (2007). "Evaluation of English language textbooks: Some important issues for consideration", in Journal of NELTA, 12, 2: 80-84.

Norris, S. P. (1985). "Synthesis of research on critical thinking", in Educational Leadership, 42: 40-45.

O’Neil, R. (1982). "Why use textbooks?", in ELT Journal, 36, 2: 104-111.

Paul, R., \& Elder, L. (2006). Critical Thinking: Tools for Taking Charge of Your Learning and Your Life ( $2^{\text {nd }}$ ed.). NJ: Pearson Prentice Hall.

Pithers, R. T., \& Soden, R. (2000). "Critical thinking in education: A review", in Educational Research, 42, 3: 237-249.

Rashid, R.A., \& Hashim, R.A. (2008, November 19-21).The Relationship between critical thinking and language proficiency of Malaysian undergraduates. Paper presented at EDU-COM International Conference, Edith Cowan University, Perth Western Australia.

Razmjoo, S., A., \& Kazempourfard, E. (2012). "On the representation of Bloom's revised taxonomy in interchange course books", in The Journal of Teaching Language Skills, 4, 1: 171-204.

Riazi, M., \& Mosalanejad, N. (2010). "Evaluation of learning objectives in Iranian high school and pre-university English textbooks using Bloom's taxonomy", in TESL-EJ, 13, 4: 1-16.

Roohani, A., Taheri, F., \& Poorzangeneh, M. (2014). "Evaluating Four Corners textbooks in terms of cognitive processes using Bloom's revised taxonomy", in RALs, 4, 2: 51-67.

Rubenfeld, M. G., \& Scheffer, B. K. (2010).Critical Thinking Tactics for Nurses: Achieving the 
IOM Competencies. Sudbury, MA: Jones \& Barlett Learning.

Schafersman, S. D. (1991). An introduction to critical thinking. Retrieved March 3, 2008 from http://www.freeinquiry.com/critical-thinking.html

Shakirova, D. M. (2007). "Technology for the shaping of college students' and upper-grade students' critical thinking", in Russian Education \& Society, 49, 9: 42-52.

Sheldon, L. (1987). ELT Textbooks and Materials: Problems in Evaluation and Development. Oxford: Modern English Publications.

, L. (1988). "Evaluating ELT textbooks and materials", in ELT Journal, 42, 4: 237-246.

Talebinezhad, M. R., \& Matou, Z. (2012). "EFL reading comprehension textbooks at university level: A critical thinking perspective", in Theory and Practice in Language Studies, 2, 8: $1746-1754$.

Thorndike, R. M. (2005). Measurement and Evaluation in Psychology and Education. Upper Saddle River, NJ: Pearson.

Tomlinson, B. (2010). "Principles of effective materials development", in N. Harwood (ed.), English Language Teaching Materials: Theory and Practice. New York: Cambridge University Press. B. (Ed.). (2008). English Language Learning Materials: A Critical Review. London, Continuum.

Ur, P. (1996). A course in Language Teaching: Practice and Theory. UK: Cambridge University Press.

Waters, A. (2006). "Thinking and language learning”, in ELT Journal, 60, 4: 237-319.

Watson, G., \& Glaser, E. M. (1994). Watson-Glaser Critical Thinking Appraisal, Form S manual. San Antonio, TX: The Psychological Corporation. , G., \& Glaser, E. M. (2012).Watson-Glaser Critical Thinking Appraisal, Technical Manual and User's Guide. San Antonio, TX: Pearson.

Zarei, A. A., \& Haghgoo, E. (2012). "The Relationship between critical thinking and L2 grammatical and lexical knowledge", in English Linguistics Research, 1, 1: 104-110. 